\title{
The use of gamification in XMOOCs about energy: Effects and predictive models for participants' learning
}

Elvira G. Rincón-Flores

School of Engineering and Sciences, Tecnologico de Monterrey, Mexico; GRIAL Research Group, University of Salamanca, Spain

\section{Juanjo Mena}

Faculty of Education, GRIAL Research Group, University of Salamanca, Spain; Institute of Psychology and Education, Kazan Federal University, Russia

\section{María Soledad Ramírez-Montoya}

School of Humanities and Education, Tecnologico de Monterrey, Mexico; GRIAL Research Group, University of Salamanca, Spain

Raúl Ramírez Velarde

School of Engineering and Sciences, Tecnologico de Monterrey, Mexico

\begin{abstract}
Open access education has significantly grown in strength as a new way of fostering innovation in schools. Such is the case of massive open online courses (MOOCs), which have the added benefit of encouraging the democratisation of learning. In this sense, the BiNational Laboratory on Smart Sustainable Energy Management and Technology Training between Mexico and the United States of America was launched with the purpose of trying MOOC technology and measuring its impact on the academic, business, and social sectors. Under this scenario, this study aimed to show the relationship between using gamification and level of performance in a MOOC on energy topics. The methodology was quantitative, using the course analytical data for socio-demographic information and predictive models. A total of 6246 participants enrolled in the MOOC and 1060 finished it. The results showed that participants aged between 20 and 50 had the highest completion rates in the gamified challenge; the higher academic degree, the more inclined participants were to solve the gamified challenge; and no such distinction exists by gender.
\end{abstract}

Implications for practice or policy:

- xMOOC participants' educational level determines the successful completion of challengebased gamification.

- Challenge-based gamification is a useful strategy for xMOOC students' evaluation.

- It is important to focus on the challenges design, if the planned challenges are not up to the students' skills, the learning results could be detrimental.

- Gamification in xMOOCs promotes participants' engagement regardless of age, gender, or educational level.

Keywords: MOOCs, gamification in education, gamified challenge, higher education, teaching methods

\section{Introduction}

In 2016, the National Council for Science and Technology, the Secretariat of Energy, and the Tecnologico de Monterrey launched in Mexico the Strategic Energy Initiative Project to develop energy reform, which aims to impact academic, business, and social communities in Mexico and Latin America, raising awareness through open innovation of sustainable energy options (Ramírez-Montoya \& García-Peñalvo, 2018; Rincón-Flores, Ramírez-Montoya, \& Mena, 2016a). The project, called Bi-National Laboratory on Smart Sustainable Energy Management and Technology Training, consists of 12 sub-projects (http://energialab.tec.mx/).

One of these sub-projects aims at interdisciplinary and collaborative innovation to teach energy sustainability through massive open online courses, also known as MOOCs. The sub-project developed MOOCs of the XMOOC type, which are characterised by being massive and self-directed. These last have 
been criticised for their strong behavioralist emphasis (Chiappe-Laverde, Hine, \& Martínez-Silva, 2015) and low average completion rates (Cabero, 2015). Also, in recent years various institutions around the world have been reluctant to include innovative pedagogical elements, such as gamification, because they can be difficult to implement (e.g., Chang \& Wei, 2016; Kyewski \& Krämer, 2018; Magaña-Valladares et al., 2016; Vaibhav \& Gupta, 2015; Willems et al., 2014).

The online course developed within the framework of the Bi-National Laboratory on Smart Sustainable Energy Management and Technology Training project was explicitly designed to include innovative pedagogical elements such as augmented reality, remote laboratories, challenge-based learning, and gamification.

For this study, we focused on the gamification-based challenge methodology - more specifically, to prove whether the use of challenge-based gamification as an innovative pedagogical strategy in an xMOOC can be influenced by socio-demographic variables (educational level, age, and gender) and test the effects of using a gamified challenge in an online course with regard to the final assessment scores. The ultimate purpose was to test whether gamification in online teaching in MOOCs improves students' learning (García-Peñalvo, García de Figuerola, \& Merlo, 2010).

According to Werbach and Hunter's model (2012), challenges are part of the mechanics element since they smoothly integrate elements of learning (Gustetic, Crusan, Rader, \& Ortega, 2015; Hamari et al., 2016) and gamification. In the same vein, activities in a game environment were designed to enable participants to apply their learning through solving a challenge-based problem (Kyewski \& Krämer, 2018; Rincón-Flores, Gallardo, \& Fuente, 2018) of the xMOOC energy course in which they were participating.

\section{Literature review}

\section{The role of MOOCs in education}

The growth of the Internet era has transformed educational systems, enabling an increase in learning opportunities within and outside educational institutions (Gómez-Zermeño, 2017). This phenomenon has encouraged the development of open access education, as it provides an opportunity to improve the transference and dissemination of knowledge (García-Peñalvo, 2015; Ramírez-Montoya, 2015; RamírezMontoya, Mena, \& Rodríguez-Arroyo, 2017) thanks to free access and the collaborative and interdisciplinary participation of various communities. MOOCs emerged from the open access and distance education movement (Ramírez-Montoya \& García-Peñalvo, 2018). In 2011, Stanford University launched the first MOOC, "Introduction to Artificial Intelligence", in which over 160,000 people enrolled (Dennis, 2012). Ever since, MOOCs have grown exponentially in various universities around the world (Del MoralPérez \& Villalustre-Martínez, 2015; Zhou, 2016). As a matter of fact, 2012 was officially called the Year of the MOOC (Chauhan, 2014).

MOOCs were created with the intention to universalise access to education and therefore promote the democratisation of education (UNESCO, 2013; Vázquez-Cano, López-Meneses, \& Sarasola 2013). Also, this type of course represents a chance to create and develop both instructional design and teaching models (Fernández-Díaz, Rodríguez-Hoyos, \& Calvo-Salvador, 2017; Hernández-Carranza, Romero-Corella, \& Ramírez-Montoya, 2015). Furthermore, Aguaded-Gómez (2013) claims that MOOCs not only grant students free access to numerous educational resources but also foster interrelationships between people from all over the world. For instance, they are a plausible way to encourage staff training in the business sector since employees can take courses anywhere any time (Olsson, 2016). This results in an advantageous situation, in terms of time and costs, to both employees and businesses.

There are currently different types of MOOC, although they are broadly categorised into two groups: xMOOCs and cMOOCs. xMOOCs are self-guided and are based on interactive multimedia such as video and text, and employ a behaviourist approach (Sánchez-Vera, León-Urrutia, \& Davis, 2015). Meanwhile, cMOOCs are based on connectivism, as they take advantage of social networks so that participants can communicate and collaborate through various online channels such as Twitter, blogs, wikis, and Facebook, (Siemens, 2005). The big difference between these two types of MOOCs is, cMOOCs focus on knowledge generation while xMOOCs focus on knowledge duplication (Siemens, 2013). There are efforts to create hybrid MOOC courses with the intention of combining the connectivity of cMOOCs and the rigid and 
controlled structure of xMOOCs (Fidalgo-Blanco, Sein-Echaluce, \& García-Peñalvo, 2016; GarcíaPeñalvo, Fidalgo-Blanco, \& Sein-Echaluce, 2018). Despite evidence that proves their benefits, it must be emphasised that many programs opt for one of them. The choice depends on the pedagogical design needs of each course, on the technological resources, and the scope (Méndez García, 2013; Ulrich \& Nedelcu, 2015). In the case of the MOOC of this research, the platform was limited to massive and free courses. As a consequence, it had to be self-directed, so the design fit in with the xMOOC.

\section{Gamification in MOOCs}

Despite XMOOCs having benefitted many people around the world, they have also been subject to criticism, mainly due to their behaviourist approach (Ping, 2013) resulting in lack of immediate feedback to students (Hone \& El Said, 2016; Xing, Chen, Stein, \& Marcinkowsky, 2016), boredom (Barak, Watted, \& Haick, 2016; Hew, 2016), low completion rates (Bartolomé-Pina \& Steffens, 2015), and difficulties in favouring the inclusion of different types of participants (Kahan, Tal, \& Nachmias, 2017). Thus, many researchers support the idea of including gamification in the pedagogical design of xMOOCs since it leads to an increase in motivation, completion rate, and even learning (Alraimi, Zo, \& Ciganek, 2014; Borrás-Gené, Martínez-Nuñez, \& Fidalgo-Blanco, 2016; Freire, Martínez-Ortiz, Moreno-Ger, \& Fernández-Manjón, 2015; Hew, Huang, Chu, \& Chiu, 2016; Kaplan \& Haenlein, 2016; Vaibhav \& Gupta, 2015).

Gamification is an innovative educational strategy that borrows elements from games to be used in nongame contexts (Marín, 2015). Its purpose is to place students in scenarios or simulations in which they can overcome appealing challenges in order to increase their engagement and competitiveness (VillalustreMartínez \& Del Moral-Pérez, 2015). Gamification is a trend with a long history: for example, badges and ranks have been awarded in the military for centuries, and leaders from the former Soviet Union used game elements to reward soldiers' performance (Dicheva, Dichev, Agre, \& Angelova, 2015). Gamification has extended to other sectors, such as businesses, marketing, health, and, in recent years, education. Companies such as Starbucks, Amazon, eBay, Heineken, and Nike have employed gamification to increase brand loyalty (Williams, 2015). In a similar fashion, gamification has made significant strides in education, thanks to the digital age and the inherent benefits of games (Hamari, 2017; Maican, Lixandroiu, \& Constantin, 2016; Mekler, Brühlmann, Opwis \& Tuch, 2013).

A gamified system, according to the model by Werbach and Hunter (2012), is made up of dynamics, mechanics, and components. Dynamics are the contexts in which the gamification occurs, mechanics are the activities within the dynamics, and the components are the objects used for the mechanics. Researchers have indicated that gamified systems in education must have three dimensions: cognitive, social, and affective (Domínguez et al., 2013; Nisbet \& William, 2009). Thus, an affective dynamic based on challenge mechanics and using appealing components such as badges, points, or trophies could increase motivation and foster learning (Rincón-Flores, Ramírez-Montoya, \& Mena, 2016b).

In this sense, challenge-based learning (Berland et al., 2013) can complement gamification and vice versa, converging in what has been called challenge-based gamification mechanics, since gamification could encourage students' commitment (Admiraal, Huizenga, Akkerman, \& Dam, 2011; Hamari et al., 2016) and challenge-based learning could motivate their creativity by setting the innovation level.

With that in mind, the following research questions were posed:

(1) What is the completion rate based on the socio-demographic characteristics of the sample?

(2) What variables (e.g., gender, age, educational level) are related to the completion of the gamification challenge?

(3) To what extent does completing the gamified challenge predict student course success (final exam score)?

\section{Methods and procedures}

This study focused on analysing a challenge-based gamification activity presented in an xMOOC about energy. The design of the gamified activity was based on Werbach and Hunter's model (2015), which stresses the emotional and social dimensions. The design of the challenging task can be considered as the mechanic component, whereas the awards (prize cups) and leader boards were the components. Participants 
experienced a range of emotions when conducting the task, especially when they received immediate social feedback as the results were shown on a leader board.

\section{The MOOC course}

The MOOC presented in this study was part of a project titled "Innovación abierta, interdisciplinaria y colaborativa para formar en sustentabilidad energética a través de MOOCs" (Open, cross-cultural, and collaborative innovation towards energy sustainability through MOOCs) within the Bi-National Laboratory on Smart Sustainable Energy Management and Technology Training (http://energialab.tec.mx). This project consisted of the development of 12 xMOOCs, on topics covering energy reform and its sustainability; for example, "La reforma energética y sus oportunidades" (Mexico's energy reform and its opportunities), "Mercados de carbon" (Carbon markets), "Introducción a la energía eléctrica" (Introduction to electric energy) (http://mexicox.gob.mx/).

The Mexican National Council for Science and Technology and the Secretariat of Energy required the researchers to include innovative teaching practices, such as gamification, in the courses. This led to the sub-project's development within an interdisciplinary and collaborative framework composed of three teams of experts: teachers and researchers on energy topics, technology developers, and an educational innovation research group. The contents of the course were uploaded on to MexicoX, an online learning platform for MOOCs. Figure 1 shows the design of the teaching architecture applied in the energy MOOCs.

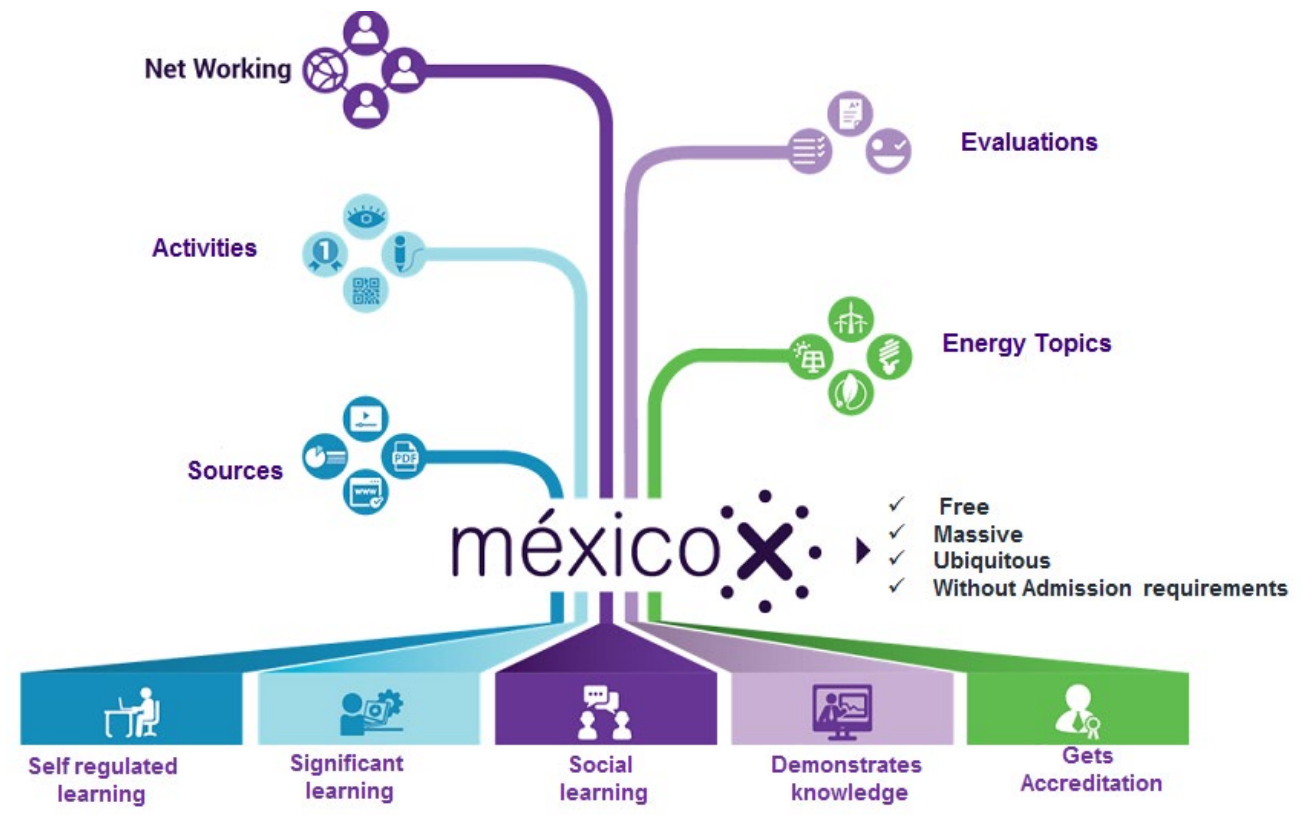

Figure 1. Design of the teaching architecture of the energy MOOCs using MexicoX (Valdivia Vazquez, Villegas, Farías, \& Aldape, 2017, p. 22)

In the present research, we focused on the course titled "Energías convencionales, limpias y su tecnología" (Conventional and clean energies and associated technology), which took place from February 28 to April 15 of 2017. The course was designed to familiarise students with the advantages and disadvantages of energy technologies for minimising negative impacts on the environment through the selection, use, and development of most of the energy sources used in daily life. The xMOOC completion was rated on a scale of 100 points where participants needed to accumulate a minimum of $60 \%$ to obtain a certificate. Out of the 100 points, $80 \%$ corresponded to regular knowledge questions and $20 \%$ to the completion of the gamified challenge.

A series of activities involving games were designed for each course. The course type determined the design and quantity of game exercises. At the end of each course, a game challenge was included, in which the participants could win a prize in the form of a golden cup if they answered correctly on the first try, a silver cup if they answered correctly on their second try, and a bronze cup if they did it on their third try. At the 
end of the challenge, the results were shown on a leader board where the participants could see their standing and that of their classmates. Figure 2 shows part of the challenge and the leader board.
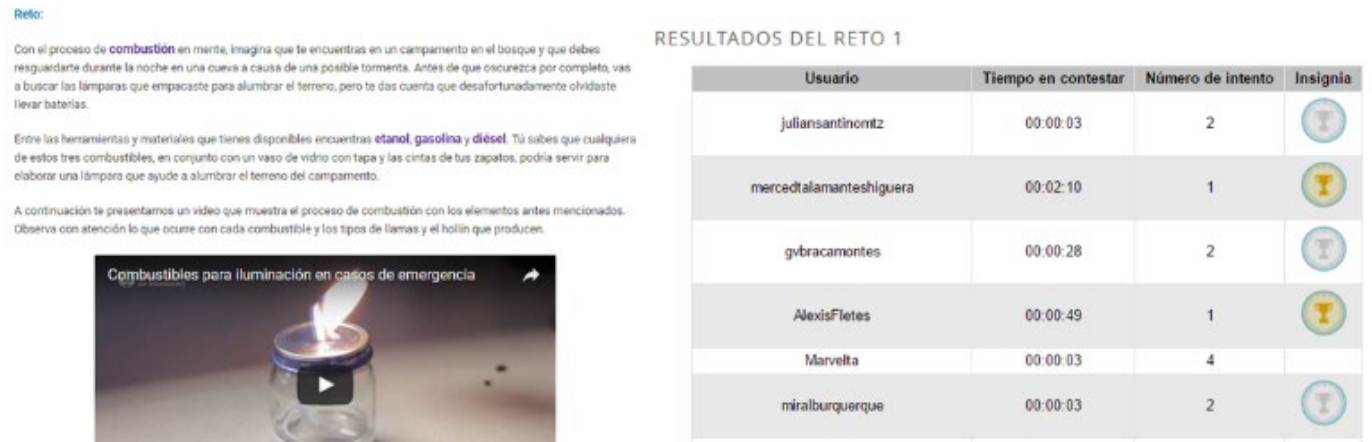

Figure 2. Partial image of the challenge and the leader board of the course "Energías convencionales, limpias y su tecnología" (Conventional and clean energies and associated technology) (Rincón-Flores, 2018, pp. 139-140)

The chosen scenario for the gamified challenge was about sheltering in a cave because of a thunderstorm. The cave had to be lit by making a lamp out of the available resources in there: a can of ethanol, diesel, or gasoline; a glass jar; and a belt. The idea was to select the best fuel to light the cave in terms of duration of light and less pollution.

\section{Research design}

The present study consisted of three phases. Phase 1 was a theoretical literature review on gamification used in MOOCs and its role in education. Phase 2 consisted of administering a questionnaire. In Phase 3, data was processed using MOOC analytics to obtain the results.

\section{Sample}

A total of 6246 participants participated in the study. Out of the total sample, 1060 students passed the xMOOC and 612 students voluntarily answered the questionnaire. The courses targeted a population over 17 years old who had finished high school, showed a marked interest in topics related to energy sustainability, and were seeking better training opportunities through online open programs. This type of training enabled participants to achieve their learning goals within a more flexible instructional environment.

\section{Data collection}

For the first research question, data was collected from a questionnaire on SurveyMonkey administered during the first week of the course. For research questions 2 and 3, the information provided by the analytics of the MéxicoX platform was used. Once the course ended, data was organised for the variables gamified challenge, final evaluation, final score, educational level, gender, and age. Items with incomplete sociodemographic data were discarded.

\section{Data analysis}

The research methodology followed a quantitative approach (Kerlinger \& Lee, 2002), and the vast data was provided by the MOOC responses' worksheet. This information was related to evaluation and sociodemographic variables. All the data was processed with Minitab, R, and XLSTAT software to conduct the following analyses:

(1) Comparison of two population proportions based on independent samples and the $Z$ statistic. The chi-square test is used when comparing more than 2 proportions. We performed these tests for discovering if gender, educational level, and age played a role in the completion rate of the gamified challenge. Also, we computed the $95 \%$ confidence intervals with continuity correction for proportions. This correction takes into account the skewed distribution of the estimation when proportions are not close to $50 \%$. Confidence intervals for proportions are used for illustration in interval plots. 
(2) Students' $t$ test to look for statistical differences between continuous variables sample means (Remenyi, Onofrei, \& English, 2009). $P$ values are used to verify the statistical significance of the evidence by which we accept or reject a hypothesis. We could be interested in finding if the means of two different random samples are the same, for example, one containing males and another containing females (called the null hypothesis). Analysis of variance (ANOVA) is used to test significant difference among means of more than two groups. We tested against differences in the final exam and final grade for gender, educational level, and age.

(3) Linear regression as a predictive technique. A continuous dependent variable is modelled as a linear combination of a set of dependent variables plus a constant and a random residual.

(4) Principal component analysis (PCA) to find the relationship between group variables. PCA is a statistical procedure that uses an orthogonal transformation to convert a set of observations of possibly correlated variables into a set of values of linearly uncorrelated variables called principal components (Jolliffe, 2012). PCA, by finding the eigenvalues and the eigenvector of the correlation matrix, determines orthogonal axis of maximum variance. Variables are projected into those orthogonal axes called these factor loadings, whereas observations, when projected into the orthogonal axis, are called factor scores. Factor loadings show how variables group together. The dimension of a dataset can be reduced when factor loadings of different variables are rather close, indicating they give the same information; therefore, some variables can be removed. Also, if independent and explanatory variables of interest are grouped together in the projection, it is indicative that there might be a causality relationship between these variables. We used PCA to find the explanatory variables for the gamified challenge, final exam, and final grade. Factor scores show how observations, or students in our case, group together. Clusters of observations may eventually be observed, suggesting similitudes and differences between groups.

(5) Point biserial correlation analysis to determine if an explanatory or independent variable influences the result of a dependent variable that has only two values. For example, we can verify if doing the gamification challenge influences having a certain score level on the final exam or final grade.

\section{Results}

\section{What is the completion rate based on the socio-demographic characteristics of the sample?}

As noted above, 6246 students enrolled in the MOOC "Energías convencionales, limpias y su tecnología" (Conventional and clean energies and associated technology), of whom 1060 passed and obtained accreditation. This means that an overall 17\% completion rate was reached (Ramírez-Montoya, García, González, Aldape, \& Farías, 2017). This percentage is considered high since, on average, the completion rate for other MOOCs in online education is around 4\% (Bartolomé-Pina \& Steffens, 2015).

The most frequent participants' age interval was 21 to 25 . As for educational level, the highest frequency belonged to undergraduate students, closely followed by high school students. Also, the fact that most of the participants were students, professionals, and teachers stands out. It is noteworthy that $10 \%$ of them were government officials and principals, which shows leaders' interest to be up to date or to learn about the topic.

Out of 1060 students who passed the final evaluation, 1025 students did the gamified challenge (97\%) and $35(3 \%)$ did not. Of the 6246 students originally enrolled, 32\% were between 21 and 25 years old, whereas $35 \%$ percent of the 1060 students who passed are in this same age interval. This suggests that there was a marked interest by participants between 21 and 25 years old (students and professionals) in taking part in the gamified challenge and that a significant fraction did pass the course. As for gender, $62 \%$ of the students originally enrolled were male. This group had the highest completion rate as they comprised $68 \%$ of the students who passed the final evaluation.

\section{What variables (e.g., gender, age, educational level) are related to the completion of the gamified challenge?}

We conducted PCA for the variables gamified challenge (the dependent variable of interest), gender, educational level, and age (explanatory variables) to identify causality relationships for gamified challenge. 
Also, we wanted to explore the association of final evaluation and final score with our explanatory variables. Because final evaluation and final score carried similar information (they were highly correlated), we included them one at a time in PCA (Figure 3). The final evaluation is an important component of the final score. Therefore, both PCA plots are very similar, and final score seems to replace final evaluation in Figures $3 \mathrm{a}$ and $3 \mathrm{~b}$.

If there is a positive correlation, the variables will be grouped together in the biplot of the factor loadings obtained from PCA. Gender factor loading is small in both biplots in Figure 3, which means that it is almost perpendicular to the plane formed by F1 (component 1) and F2 (component 2). Thus, there is not a strong association between gender and gamified challenge. This is consistent with the $t$ test, which shows that there is no statistically significant difference between males and females in the gamified challenge completion rate with a $p$ value of 0.169 . F1 and F2 are independent linear combinations of the original variables. In this case, F1 is the linear combination that explains as much of the data variance as possible. As noted in Figure 3, the projection of gender into the F1 axis is small, which means that F1 includes this variable to a lesser extent compared to the rest of the variables. F2 is the linear combination uncorrelated to $\mathrm{F} 1$ that accounts for as much of the remaining variability as possible. By choosing the components that explain the most data variability, PCA makes it possible to plot more than two variables in a twodimensional plane with high accuracy.

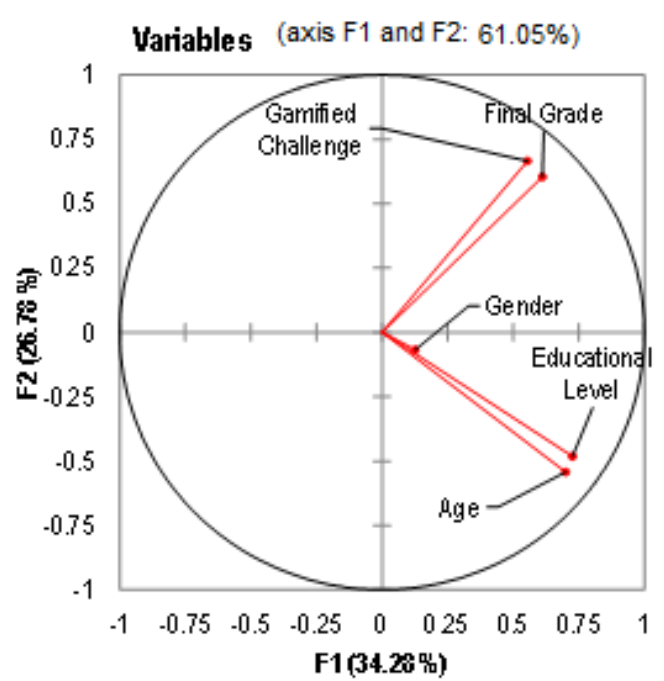

(a)

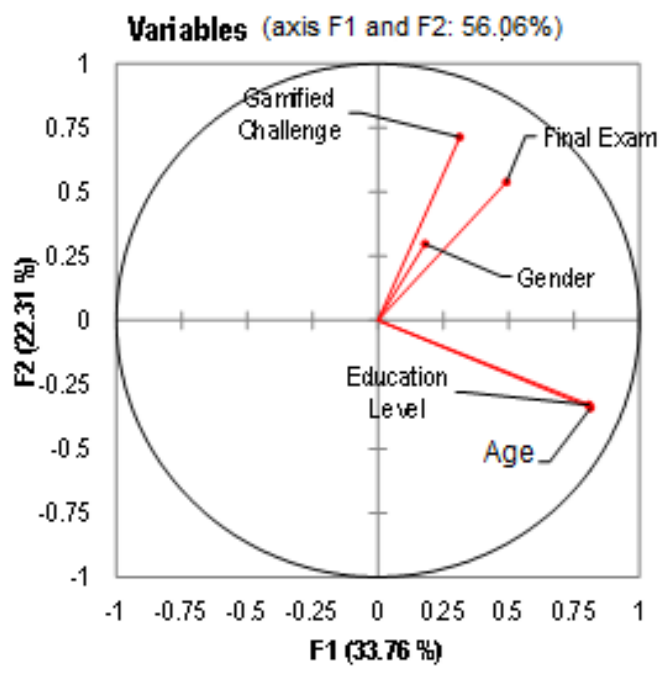

(b)

Figure 3. PCA correlation biplot identifying association between variables. F1 and F2 represent the two principal components.

Figure 4 shows a slight tendency for males to be more likely to do the gamified challenge than females. However, the difference is not statistically significant as the confidence intervals are overlapped. 


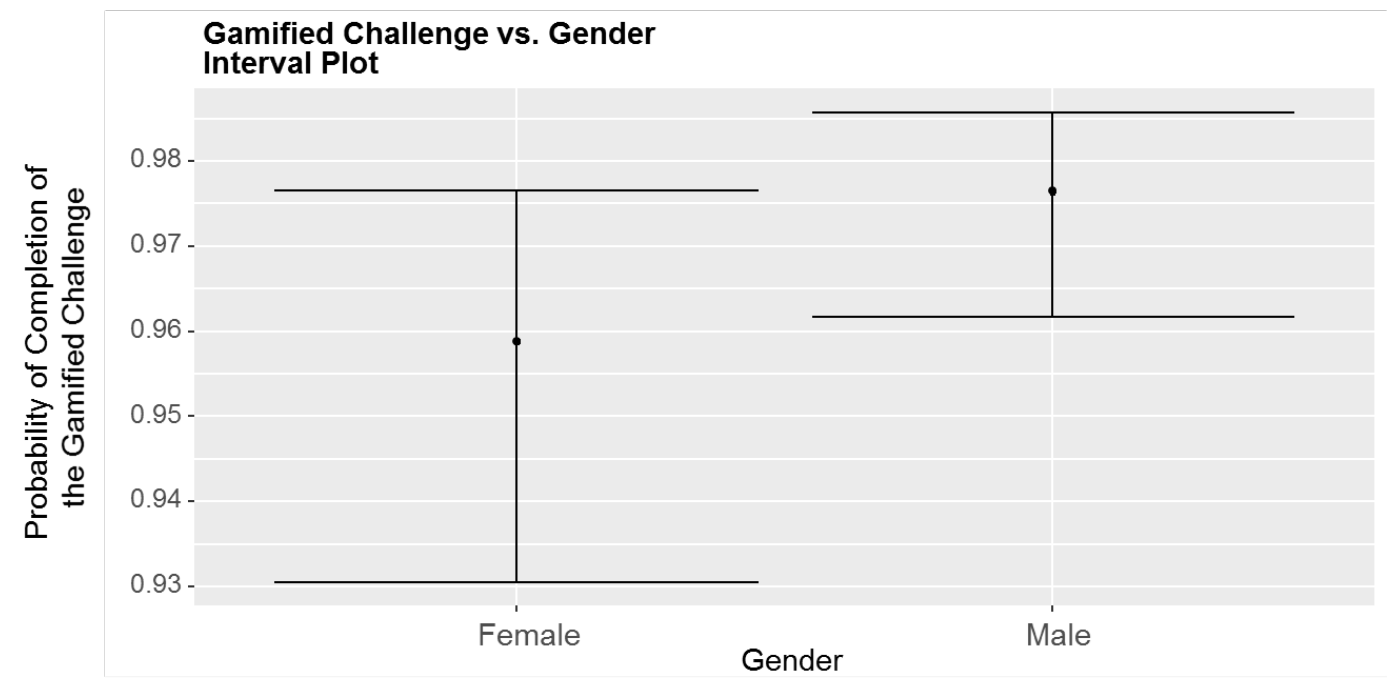

Figure 4. Interval plot for the proportion of participants who finished the gamified challenge by gender

When testing the educational level and the odds of completing the gamified challenge, we found that there are statistically significant differences ( $p$ value $=0.0159$ ). The means of the six types of educational levels are not statistically equal in terms of completion rate of the gamified challenge (Figure 5).

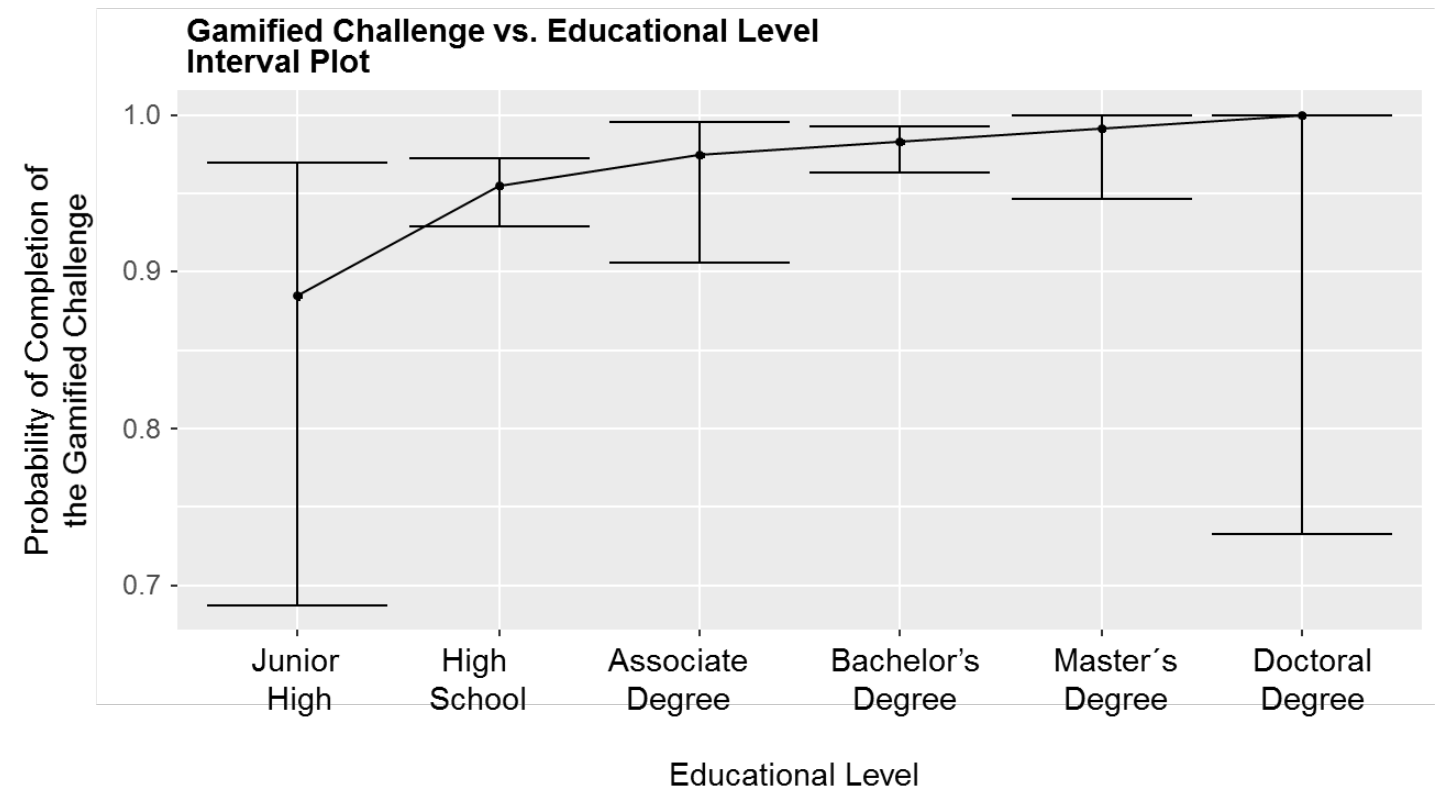

Figure 5. Interval plot for the proportion of participants who completed the gamified challenge by educational level

When testing against differences in the gamified challenge based on age, we found that there are significant statistical differences between different ages $(p$ value $=0.0114)$. Although results are not better as age increases, there is an age range in which the completion rate is higher, which is from 26 to 50 years (Figure $6)$. 


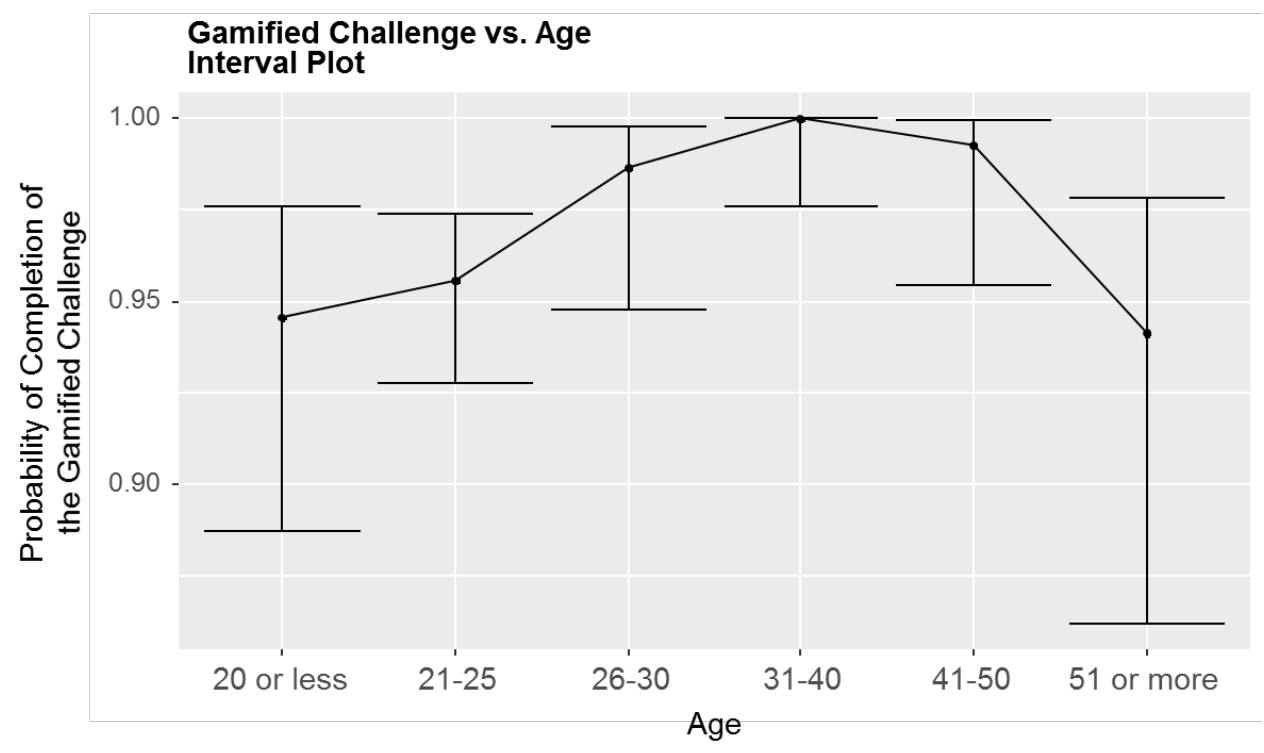

Figure 6. Interval plot for the proportion of participants who completed the gamified challenge by age

We identified correlations for final grade using PCA in Figure 3(a), which includes the variables gamified challenge, gender, educational level, age, and final grade. Figure 3(a) indicates that there is an association between final grade and gamified challenge ( $\underline{p}$ value $<0.0001)$. We found that the final score of those who completed the gamified challenge (average of 0.81) was statistically different from those who did not (average of 0.45). The $t$ test also showed that there were no significant differences in the final score between males and females $(p$ value $=0.990)$. However, when testing against differences related to educational level, we found that there were statistically significant differences $(p$ value $=0.001)$. The mean scores of the six educational levels were not statistically equal. In general terms, the three more advanced educational levels obtained a better average than the first three educational levels. When testing against differences in final score based on age, we found that there were significant statistical differences between different ages ( $p$ value $=0.034)$. Nevertheless, there was only a slight trend that tells us that final score improves as age increases (Figure 7).

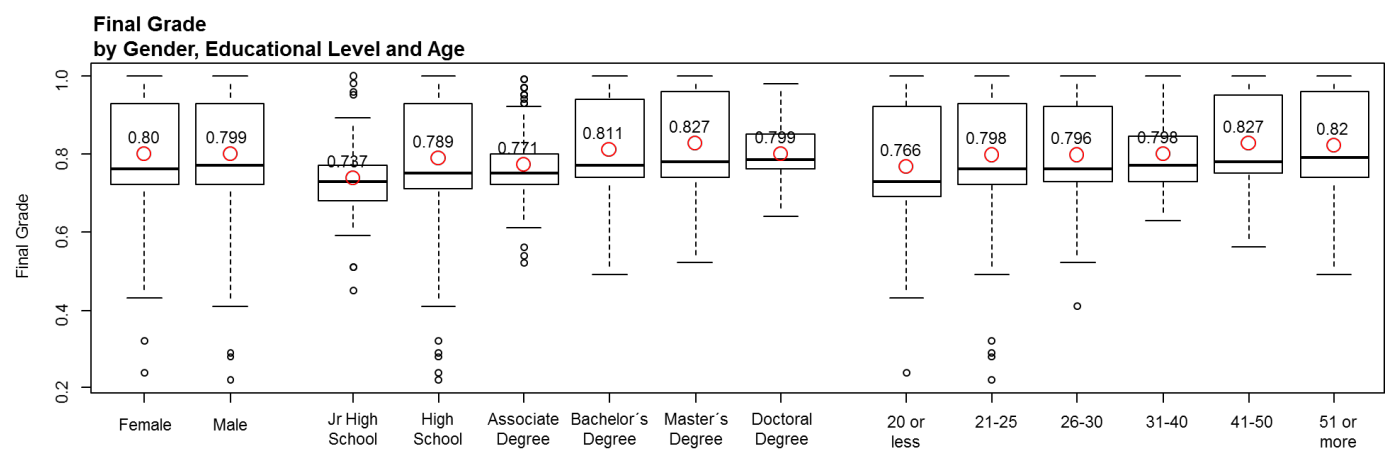

Figure 7. Box plots for final grade by gender, educational level, and age. The red circle represents the mean. The mean is labelled in each box.

Figure 3(b) includes the variables gamified challenge, gender, educational level, age, and final evaluation, and we focused on identifying associations for final evaluation. Figure $3 \mathrm{~b}$ indicates that there is a causality relationship between final evaluation and gamified challenge. We found that the final evaluation mean score of those who did the gamified challenge was statistically different than those who did not ( $p$ value $<$ $0.0001)$. The final evaluation mean of students who did the gamified challenge was 0.91 , whereas it was 0.78 for those who did not.

The $t$ test shows that the means between males and females on the final evaluation were not the same ( $p$ value $=0.028$ ). Males had a mean score of 0.91 , whereas females 0.90 (recall that there were no statistical 
differences between males and females for gamified challenge). As for final evaluation and education level, with $p$ value $<0.0001$, the means of the different education levels were not the same. There was a clear trend to get a higher score on the final evaluation as education level increases.

When testing differences in final exam based on age, we found that there were significant statistical differences between different ages $(p$ value $=0.015)$.

\section{To what extent does completing the gamified challenge predict student course success completion (final exam)?}

Predictive models were used to explain the course students' success (final evaluation scores) based on the variables educational level, gender, age, and gamified challenge.

A multiple linear regression model was built with final exam as a dependent variable. Since our sample was comprised of 1060 students who passed the exam, this score ranged from 0.6 to 1 . For simplicity, let's scale it to 60 to 100. First, we checked for multicollinearity and found that age and educational level are variables with a high correlation index (0.54). In order to avoid multicollinearity in our regression model, we excluded educational level and included age because age is the variable that correlates the most with the final evaluation. Then, we performed backward elimination in order to get a model with only significant independent variables. In our first run, gender was shown as a not significant variable ( $p$ value $=0.1190)$, so we excluded gender. We already had seen that final score is not statistically different for males and females and the difference in the final evaluation was only 1\%. Finally, with our second run, our model includes two significant variables: age ( $p$ value $<0.0001)$ and gamified challenge $(p$ value $=0.0006)$. The $R^{2}$ was 0.0451 for the linear fit:

$$
\text { final evaluation score }=81.86+5.31(\text { gamified challenge })+0.14(\text { age })
$$

This means that, on average, 5.31 more points were scored in the final evaluation if the student completed the gamified challenge and 1.4 more points are scored per every 10 more years of age.

We decided to put the variable Educational level into play by building a model that predicts an estimate of the percentage of students that will do the challenge. This is shown in Figure 8 . The $R^{2}$ is 0.7734 for the linear fit:

$$
\text { probability of gamified challenge completion }=0.8945+0.0194 \text { (educational level) }
$$

where educational level is as follows: $1=$ junior high school, $2=$ high school, $3=$ associate degree, $4=$ bachelor's degree, $5=$ master's degree, and $6=$ doctorate degree. The linear model shows that, on average, there is an extra $1.94 \%$ of probability of completing the gamified challenge for each additional educational level (see Figure 9).

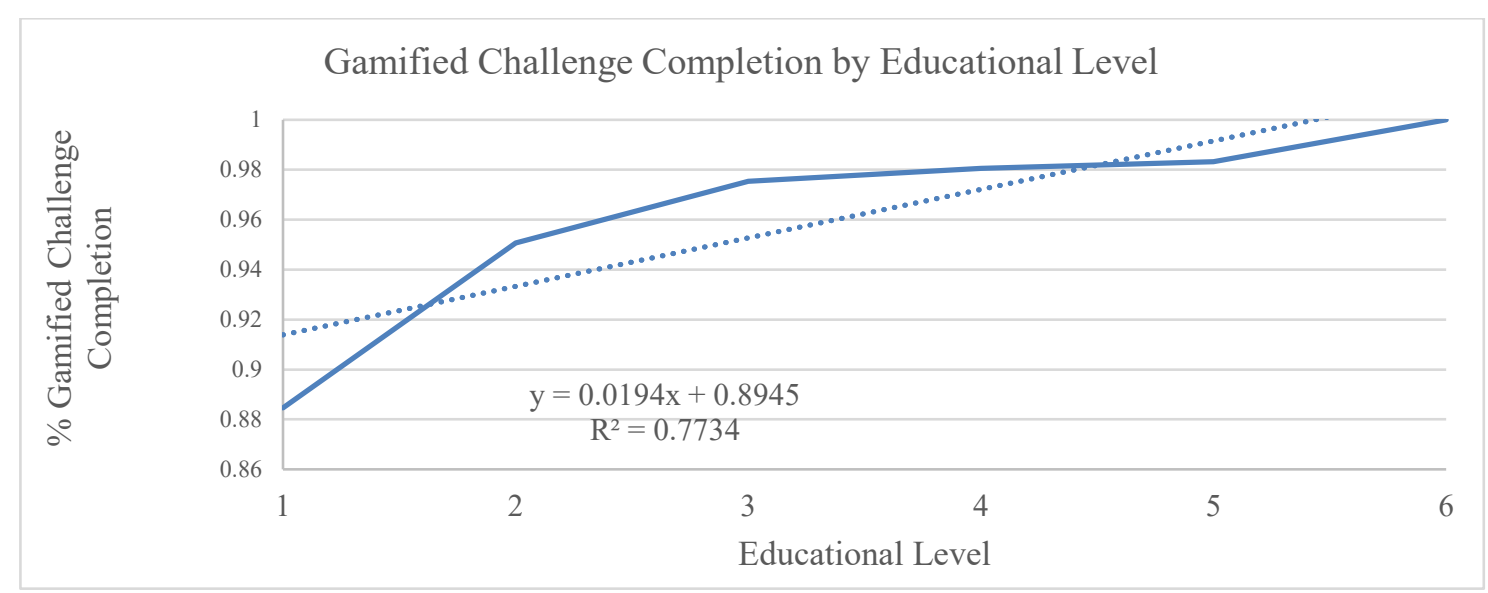

Figure 8. Linear fit for the percentage of students who completed the gamified challenge by educational level 
To support the results from the prediction model, a clustering for the variables gamified challenge, age, gender, educational level, and final exam was conducted. Table 1 shows the squared cosines for PCA with the variables that are shown in Figure 3b. F1 is the principal component that explains more variability and it is mainly related to education level and age, whereas F2 is mainly related to the gamified challenge. This means that, based on the results of the Figure $3 \mathrm{~b}$ and Table 1, older students with high education tend to have a high value of component F1 and students who undertook the gamified challenge tend to have a high value of component F2. Based on the results of the Figure 7 and Table 1, older students with high education are related with component F1 and students who undertook the gamified challenge are related with component F2.

Table 1

Squared cosines for PCA in Figure $3 b$

\begin{tabular}{lcccc} 
& F1 & F2 & F3 & F4 \\
\hline Gamified challenge & 0.098 & $\mathbf{0 . 5 1 1}$ & 0.085 & 0.301 \\
Age & $\mathbf{0 . 6 6 2}$ & 0.117 & 0.005 & 0.000 \\
Gender & 0.033 & 0.089 & $\mathbf{0 . 8 6 7}$ & 0.008 \\
Education level & $\mathbf{0 . 6 5 3}$ & 0.108 & 0.008 & 0.025 \\
Final evaluation & 0.242 & 0.291 & 0.019 & $\mathbf{0 . 4 4 7}$ \\
\hline
\end{tabular}

Note. F1, F2, F3, and F4 are the first four principal components in descending order by percentage of variability represented.

In Figure 9, we plotted F1 versus F2 principal component sample scores for a random sample of 250 transformed observations. As mentioned before, the horizontal axis was mainly related to education level and age, whereas the vertical axis was mainly related to gamified challenge.

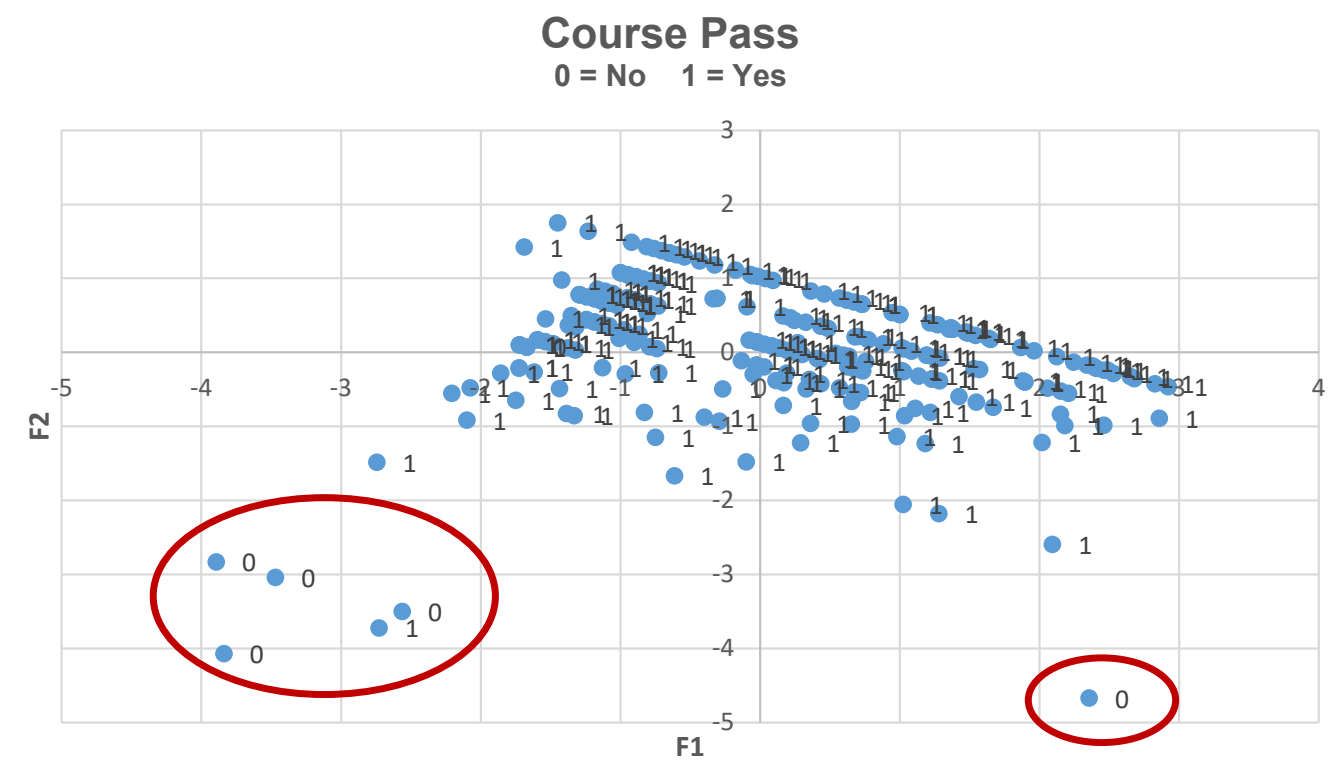

Figure 9. Clustering by plotting F1 vs F2. Red ovals indicate students with low F2. F1 and F2 represent the two principal components.

Figure 9 also shows that students with very low F2 (associated with gamified challenge) will likely not pass the course, and that many students with low value of F2 also have low value of F1 (associated with age and educational level). The big oval in the picture represents students with low values of both F1 and F2 who are most likely to fail the course. The shape of the cloud of points observed in the plot is explained by the high correlation between educational level and gamified challenge and by the binary nature of the gamified challenge. This means a student with higher level of education is more likely to do the gamified challenge.

Finally, the biserial point correlation helped to determine whether the variables gamified challenge and final exam are related to each other as well as gamified challenge and final grade. For both tests, we used 
a significance level of $5 \%$ and we obtained a $p$ value $<0.0001$; therefore, the null hypothesis can be rejected. In other words, solving the gamified challenge is indeed related to achieving better scores in the final exam and having a better final grade.

\section{Discussion}

The objective of this study was to determine the relationship between challenge-based gamification in an xMOOC on issues of energy sustainability and the participants' academic performance based on sociodemographic data. One of the most significant results is that, out of the 6246 enrolled students, 1060 passed the final exam; that is, the completion rate reached $17 \%$. This high percentage is relevant, considering that xMOOC completion rates are usually low (Bartolomé-Pina \& Steffens, 2015). According to Armstrong (2014) in a study carried out in Coursera, the completion rate was $4 \%$, although Liyanagunawardena, Parslow, and Williams (2014) maintain that the global average completion rate is of around 10\%. Therefore, the findings align with the objective of the Bi-National Laboratory on Smart Sustainable Energy Management and Technology Training project and turned out to be positive, especially as it is an xMOOC that teaches issues of energy sustainability.

One of the reasons that might explain this success is the genuine interest the participants showed in the course contents. The courses were especially designed to reach regular participants with average knowledge about the topic. Also, being able to get a certificate motivated some of the participants to complete the course. Almost all participants who succeeded in passing the course completed the gamified challenge. This reveals that there is an interest for this type of activity. The fact that a higher completion rate was obtained (compared to similar xMOOCs worldwide) might be partly explained by the intriguing gamification activities for the participants.

Regarding the gender, it was observed that there was no significant difference in the participation of men and women in the gamified challenge, disproving the wide-assumed belief that games are preferred by men. This contradicts the study by Lenhart et al. (2008), who found that $99 \%$ of the male participants is willing to play, while $94 \%$ of the female participants are willing to do so. It is interesting that in the MOOC of this study, men and women were equally willing to participate in a gamified activity. Meanwhile, regarding age, a $U$ shape relation was observed between this variable and gamification. Higher completion rates were found in ages 26 to 50, which breaks the myth that technology is more used by the so-called millennial generation. Also, a correlation was found between the academic level and the gamified challenge. In other words, the higher the academic degree, the more inclined participants were to solve the challenge. These findings corroborate Huizinga's (2012) work, who argues that play is as old as culture itself and, therefore, it not only provides entertainment, but a way of learning.

Another interesting correlation was found between the final exam and the educational level. That is, the higher the educational level, the greater the participation in the gamified activity and the better grade in the final exam. This result confirms the importance of the cognitive aspect in gamification (Domínguez et al., 2105; Hamari et al., 2016; Nisbet \& Williams, 2009) since it promotes intrinsic motivation. The majority of the participants who passed the final exam completed the gamified challenge but less than $3 \%$ of this success can be attributed to the online course methodology. This result might seem daunting; however, it should be considered that this is a traditional MOOC course in which, despite incorporating the gamification technique, the MOOC assessment still relies on traditional methods. This is not an open criticism of the xMOOC methodology, rather we raise it as a limitation - the fact that xMOOCs are characteristically massive causes technological difficulties for implementing gamification.

\section{Conclusion}

MOOCs have been criticised because they rely on behaviouralist approaches and the completion rates are usually low in spite of the benefits of free access and academic prestige (many of them are offered by world-class institutions). Our study might be relevant because we claim that gamification can be applied as an innovative didactic strategy in XMOOCs, which are massive online learning environments that are selfmanaged by the participants.

Our first conclusion is that gamification may enhance motivation in XMOOC students. Although we did not find conclusive evidence that gamification was the cause of a completion rate higher than the world 
average, it is worth noting that a high percentage of students who finished the activity passed the final test and finished the course. This fact suggests that gamification is a strategy that may motivate students to stay active during a large portion of the course. Besides, the topics in the xMOOC "Conventional and clean energies and associated technology" are of importance in the energy reform process in Mexico.

Secondly, this study found that both males and females participated to the same extent in the gamified activity. This is contrary to some investigations that suggest that males are more inclined to get involved in activities that include games. The pedagogical design of the gamification may have played a role in this result because the gamified activity was developed in an environment of constructive competition where all participants had the same chances to win and be recognised.

The investigation revealed that people between 26 and 50 years old were the most involved in the gamified activity. Also, enthusiasm to complete the activity grows as academic level increases. Overall, we can say that gamification is an innovative didactic strategy that helps to improve the pedagogical architecture of the XMOOCs and that stimulates the engagement of all participants regardless of age, gender, and educational level.

However, we need to acknowledge the technological limitations of the platform that hosted the xMOOC. Although the course included a gamified challenge that covered most of the course topics, the rest of the course was solely multiple-choice assessments due to the fact that this type of MOOC is characterised for being self-managed and we needed to guarantee its massiveness. Thus, we could not implement a more sophisticated gamification design based on constructivist approaches. Therefore, although technical limitations of including gamified challenges in xMOOC courses exist, it makes us consider that educational programs must tackle those difficulties and grant funding to guarantee more quality-based ways of teaching.

For future research, it would be worthwhile studying the extent to which gamification contributes to the improvement of completion rates as well as to canvassing participants' opinions on using gamification. Although this study's xMOOC on energy had a completion rate of $17 \%$, there is no conclusive evidence that such a rate was due to gamification. On the other hand, it is suggested that the technological platform used could provide more information about the performance of the challenge in order to establish more relationships between the variables. Finally, as a next step, it would be desirable to run the same research using several xMOOCs on energy subjects with the idea of developing more comprehensive comparative analysis including multiple variables.

\section{Acknowledgements}

This research was undertaken in the Knowledge Society PhD Program of the University of Salamanca, Spain.

\section{Funding}

This research was undertaken in the framework of Project 266632 "Laboratorio Binacional para la Gestión Inteligente de la Sustentabilidad Energética y la Formación Tecnológica" (Bi-National Laboratory on Smart Sustainable Energy Management and Technology Training) with financing from the energy sustainability fund CONACYT-SENER (Agreement: S0019-2014ᄀ01).

\section{References}

Admiraal, W., Huizenga, J., Akkerman, S., \& Dam, G. T. (2011). The concept of flow in collaborative game-based learning. Computers in Human Behavior, 27(3), 1185-1194. https://doi.org/10.1016/j.chb.2010.12.013

Aguaded-Gómez, J. (2013). The MOOC revolution: A new form of education from the technological paradigm? Comunicar, XXI(4), 7-8. https://doi.org/10.3916/C41-2013-a1

Alraimi, K. M., Zo, H., \& Ciganek, A. P. (2014). Understanding the MOOCs continuance: The role of openness and reputation. Computers \& Education, 80, 28-38. https://doi.org/10.1016/j.compedu.2014.08.006 
Armstrong, L. (2014). 2013 - the year of ups and downs for the MOOCs. Changing Higher Education. Retrieved from https://www.changinghighereducation.com/2014/01/2013-the-year-of-themoocs.html?goback=.gde 2774663 member 5832211875772788740 -!

Barak, M., Watted, A., \& Haick, H. (2016). Motivation to learn in massive open online courses: Examining aspects of language and social engagement. Computers \& Education, 94, 49-60. https://doi.org/10.1016/j.compedu.2015.11.010

Bartolomé-Pina, A. R. \& Steffens, K. (2015). ¿Son los MOOC una alternativa de aprendizaje? [Are MOOCs promising learning environments?]. Comunicar, XXII(44), 91-99. https://doi.org/10.3916/C44-2015-10

Berland, L. K., Martin, T. H., Ko, P., Peacock, S. B., Rudolph, J. J., \& Golubski, C. (2013). Student learning in challenge-based engineering curricula. Journal of Pre-College Engineering Education Research (J-PEER), 3(1), 53-64. https://doi.org/10.7771/2157-9288.1080

Borrás-Gené, O., Martínez-Núñez, M., \& Fidalgo-Blanco, Á. (2016). New challenges for the motivation and learning in engineering education using gamification in MOOC. International Journal of Engineering Education, 32(1), 501-512. Retrieved from https://www.ijee.ie/latestissues/Vol32$1 \mathrm{~B} / 19$ ijee3155ns.pdf

Cabero, J. (2015). Visiones educativas sobre los MOOC [Educational perspectives on MOOCs]. Revista Iberoamericana de Educación a Distancia (RIED), 18(2), 39-60. https://doi.org/10.5944/ried.18.2.13718

Chang, J., \& Wei, H. (2016). Exploring engaging gamification mechanics in massive online open courses. Educational Technology \& Society, 19(2), 177-203. https://www.j-ets.net/ETS/journals/19 2/14.pdf

Chauhan, A. (2014). Massive open online courses (MOOCS): Emerging trends in assessment and accreditation. Digital Education Review, 25(1), 7-18. https://doi.org/10.1344/der.2014.25.7-17

Chiappe-Laverde, A., Hine, N., \& Martínez-Silva, J. A. (2015). Literature and practice: A critical review of MOOCs. Comunicar, XXII(44), 09-18. https://doi.org/10.3916/C44-2015-01

Del Moral-Pérez, M. E., \& Villalustre-Martínez, L. (2015). MOOC: Digital ecosystems for the construction of PLE in higher education. Revista Iberoamericana de Educación a Distancia (RIED), 18(2), 87-117. http://doi.org/10.5944/ried.18.2.13353

Dennis, M. (2012). The impact of MOOCs on higher education. College and University, 88(2), 24-30. Retrieved from http://www.learntechlib.org/p/92364/

Dicheva, D., Dichev, C., Agre, G., \& Angelova, G. (2015). Gamification in education: A systematic mapping study. Educational Technology and Society, 18(3), 75-88. Retrieved from https://www.jets.net/ETS/journals/18 3/6.pdf

Domínguez, A., Saenz-De-Navarrete, J., De-Marcos, L., Fernández-Sanz, L., Pagés, C., \& MartínezHerráiz, J. J. (2013). Gamifying learning experiences: Practical implications and outcomes. Computers and Education, 63, 380-392. http://doi.org/10.1016/j.compedu.2012.12.020

Fernández-Díaz, E., Rodríguez-Hoyos, C., \& Calvo-Salvador, A. (2017). The pedagogic architecture of MOOC: A research project on educational courses in Spanish. The International Review of Research in Open and Distributed Learning, 18(6), 18-35. https://doi.org/10.19173/irrodl.v18i6.2964

Fidalgo-Blanco, Á., Sein-Echaluce, M. L., \& García-Peñalvo, F. J. (2016). From massive access to cooperation: Lessons learned and proven results of a hybrid xMOOC/cMOOC pedagogical approach to MOOCs. International Journal of Educational Technology in Higher Education, 13(24), 1-13. https://doi.org/10.1186/s41239-016-0024-z

Freire, M., Martínez-Ortiz, I., Moreno-Ger, P., \& Fernandez-Manjón, B. (2015). Requirements for educational games in MOOCs. In EDUCON 2015: Proceedings of the IEEE Global Engineering Education Conference (pp. 993-997). IEEE. https://doi.org/10.1109/EDUCON.2015.7096094

García-Peñalvo, F. J. (2015). Mapa de tendencias en Innovación Educativa. Teoría de la Educación Sociedad de la Información (TESI), 16(4), 6-23. https://doi.org/10.14201/eks2015164623

García-Peñalvo, F. J., Fidalgo-Blanco, Á., \& Sein-Echaluce, M. L. (2018). An adaptive hybrid MOOC model: Disrupting the MOOC concept in higher education. Telematics and Informatics, 35(4), 10181030. https://doi.org/10.1016/j.tele.2017.09.012

García-Peñalvo, F. J., García de Figuerola, C., \& Merlo, J. A. (2010). Open knowledge: Challenges and facts. Online Information Review, 34(4), 520-539. https://doi.org/10.1108/14684521011072963

Gómez-Zermeño, M.G. (2017). Internet y educación de calidad. In M. G. Gómez-Zermeño (Ed.), Sociedad, internet y cultura, conceptos clave y nuevas tendencias [Society, Internet and culture, key concepts and new trends] (pp. 155-170). Mexico City, Mexico: Editorial Porrúa.

Gustetic, J. L., Crusan, J., Rader, S., \& Ortega, S. (2015). Outcome-driven open innovation at NASA. Space Policy, 34, 11-17. https://doi.org/10.1016/j.spacepol.2015.06.002 
Hamari, J. (2017). Do badges increase user activity? A field experiment on the effects of gamification. Computers in Human Behavior, 71, 464-478. https://doi.org/10.1016/j.chb.2015.03.036

Hamari, J., Shernoff, D. J., Rowe, E., Coller, B., Asbell-Clarke, J., \& Edwards, T. (2016). Challenging games help students learn: An empirical study on engagement, flow and immersion in game-based learning. Computers in Human Behavior, 54, 170-179. https://doi.org/10.1016/j.chb.2015.07.045

Hernández-Carranza, E. E., Romero-Corella, S. I., \& Ramírez-Montoya (2015). Evaluation of digital didactic skills in massive open online courses: A contribution to the Latin American Movement. Comunicar, XXII(44), 81-90. http://doi.org/10.3916/C44-2015-09

Hew, K. F. (2016). Promoting engagement in online courses: What strategies can we learn from three highly rated MOOCS. British Journal of Educational Technology, 47(2), 320-341. https://doi.org/10.1111/bjet.12235

Hew, K. F., Huang, B., Chu, K. W. S., \& Chiu, D. K. W. (2016). Engaging Asian students through game mechanics: Findings from two experiment studies. Computers and Education, 92-93, 221-236. https://doi.org/10.1016/j.compedu.2015.10.010

Hone, K. S., \& El Said, G. R. (2016). Exploring the factors affecting MOOC retention: A survey study. Computers \& Education, 98, 157-168. https://doi.org/10.1016/j.compedu.2016.03.016

Huizinga, J. (2012). Homo Ludens. Madrid, Spain: Alianza. https://doi.org/ 10.5117/9789089640031

Jolliffe, I. T. (1986). Principal component analysis and factor analysis. In Principal component analysis (pp 115-128). https://doi.org/10.1007/978-1-4757-1904-8 7

Kahan, T., Tal, S., \& Nachmias, R. (2017). Types of participant behavior in a massive open online course. International Review of Research in Open and Distributed Learning, 18(6), 52-53. https://doi.org/10.19173/irrodl.v18i6.3087

Kaplan, A. M., \& Haenlein, M. (2016). Higher education and the digital revolution: About MOOCs, SPOCs, social media, and the Cookie Monster. Business Horizons, 59(4), 441-450. https://doi.org/10.1016/j.bushor.2016.03.008

Kerlinger, F. \& Lee, H. (2002). Investigación del Comportamiento. Métodos de investigación en Ciencias Sociales. Cuarta edición. [Research on behaviour: Research methods in social sciences (4th edn)]. Mexico, City: MacGraw-Hill.

Kyewski, E., \& Krämer, N. C. (2018). To gamify or not to gamify? An experimental field study of the influence of badges on motivation, activity, and performance in an online learning course. Computers and Education, 118, 25-37. https://doi.org/10.1016/j.compedu.2017.11.006

Lenhart, A., Kahne, J., Middaugh, E., Rankin Macgill, A., Evans, C., \& Vitak, J. (2008). Teens, video games, and civics: Teens' gaming experiences are diverse and include significant social interaction and civic engagement. Pew Internet \& American Life Project, 13(3)1-64. https://doi.org/10.1016/j.chembiol.2006.01.005

Liyanagunawardena, T. R., Parslow, P. \& Williams, S. (2014). Dropout: MOOC participants' perspective. In EMOOCs 2014: Proceedings of the Second MOOC European Stakeholders Summit (pp. 95-100).

Retrieved from http://centaur.reading.ac.uk/36002/2/MOOC\%20Dropout $\% 20$ Participants $\% 20$ Perspective.pp95100.pdf

Magaña-Valladares, L., González-Robledo, M. C., Rosas-Magallanes, C., Mejía-Arias, M. Á., ArreolaOrnelas, H., \& Knaul, F. M. (2016). Training primary health professionals in breast cancer prevention: Evidence and experience from Mexico. Journal of Cancer Education, 33(1) 1-7. https://doi.org/10.1007/s13187-016-1065-7

Maican, C., Lixandroiu, R., \& Constantin, C. (2016). Interactivia.ro - A study of a gamification framework using zero-cost tools. Computers in Human Behavior, 61, 186-197. https://doi.org/10.1016/j.chb.2016.03.023

Marín, V. (2015). Educative gamification: An alternative to creative learning. Digital Education Review, 27, 5-8. Retrieved from http://revistes.ub.edu/index.php/der/article/view/13433/pdf

Mekler, E. D., Brühlmann, F., Opwis, K., \& Tuch, A. N. (2013). Do points, levels and leaderboards harm intrinsic motivation? In Gamification '13: Proceedings of the First International Conference on Gameful Design, Research, and Applications (pp. 66-73). New York, NY: ACM. https://doi.org/10.1145/2583008.2583017

Méndez García, C. (2013). Diseño e implementación de cursos abiertos masivos en línea (MOOC): expectativas y consideraciones prácticas [Design and implementation of massive online open courses (MOOCs): Expectations and practical recommendations]. RED: Revista de Educación a Distancia, 39. Retrieved from https://www.um.es/ead/red/39/mendez.pdf 
Nisbet, S., \& Williams, A. (2009). Improving students' attitudes to chance with games and activities. Australian Mathematics Teacher, 65(3), 25-37. Retrieved from ERIC database. (EJ859754)

Olsson, U. (2016). Open courses and MOOCs as professional development - is the openness a hindrance? Education + Training, 58(2), 229-243. https://doi.org/10.1108/ET-01-2015-0006

Ping. W. (2013). The latest development and application of massive open online course: From cMOOC to xMOOC. Modern Distance Education Research. Retrieved from http://en.cnki.com.cn/Article en/CJFDTOTAL-XDYC201303005.htm

Ramírez-Montoya, M. S. (2015). Acceso abierto y su repercusión en la Sociedad del Conocimiento: Reflexiones de casos prácticos en Latinoamérica [Open access and its impact on the Knowledge Society: Reflections on case studies in Latin America]. Educational Knowledge Society EKS, 16(1), 103-118. https://doi.org/10.14201/eks2015161103118

Ramírez-Montoya, M.S., García, C., González, S., Aldape, P. \& Farías, S. (2017). Estadísticas de Impartición de MOOC's en abril 2017 [Presentación del Proyecto 266632 Laboratorio Binacional para la Gestión Inteligente de la Sustentabilidad Energética y Formación Tecnológica] [MOOC delivery statistics in April 2017 [Project presentation 266632 Bi-National Laboratory on Smart Sustainable Energy Management and Technology Training]. Monterrey, México: Tecnológico de Monterrey. Retrieved from http://hdl.handle.net/11285/622441

Ramírez-Montoya, M. S., Mena, J., \& Rodríguez-Arroyo, J. A. (2017). In-service teachers' selfperceptions of digital competence and OER use as determined by a xMOOC training course. Computers in Human Behaviour, 77, 356-364. https://doi.org/10.1016/j.chb.2017.09.010

Ramírez-Montoya, M. S., \& García-Peñalvo, F. J. (2018). Co-creation and open innovation: Systematic literature review. Comunicar, 26(54), 9-18. https://doi.org/10.3916/C54-2018-01

Remenyi, D., Onofrei, G., \& English, J. (2009). An introduction to statistics using Microsoft Excel. Reading, United Kingdom: Academic Publishing Ltd.

Rincón-Flores, E. G., Ramírez-Montoya, M. S., \& Mena, J. (2016a). Challenge-based gamification as a teaching' open educational innovation strategy in the energy sustainability area. In F. J. GarcíaPeñalvo (Ed.), TEEM '16: Proceedings of the Fourth International Conference on Technological Ecosystems for Enhancing Multiculturality (pp. 1127-1131). New York, NY: ACM. https://doi.org/10.1145/3012430.3012658

Rincón-Flores, E. G., Ramírez-Montoya, M. S., \& Mena, J. (2016b). Challenge-based gamification and its impact in teaching mathematical modeling. In F. J. García-Peñalvo (Ed.), TEEM '16: Proceedings of the Fourth International Conference on Technological Ecosystems for Enhancing Multiculturality (pp. 771-776). New York, NY: ACM. https://doi.org/10.1145/3012430.3012605

Rincón-Flores, E. G., Gallardo, K., \& Fuente, J. M. d. 1. (2018). Strengthening an educational innovation strategy: Processes to improve gamification in calculus course through performance assessment and meta-evaluation. IEJME-Mathematics Education, 13(1), 1-11. https://doi.org/10.12973/iejme/2692

Rincón-Flores, E. G. (2018). Gamificación en ambientes masivos de innovacion abierta en el área de sustentabilidad energética [Gamification in massive open innovation environments in the area of energy sustainability] (PhD thesis). University of Salamanca, Spain. Retrieved from https://knowledgesociety.usal.es/sites/default/files/tesis/tesis_elvira vf.pdf

Sánchez-Vera, M., León-Urrutia, M., \& Davis, H. (2015). Challenges in the creation, development and implementation of MOOCs: Web Science Course at the University of Southampton. Comunicar, 22(44), 37-44. https://doi.org/10.3916/C44-2015-04

Siemens, G. (2005). Connectivism: A learning theory for a digital age. International Journal of Instructional Technology and Distance Learning, 2(1), 3-6. Retrieved from http://itdl.org/journal/jan_05/article01.htm

Siemens, G. (2013). Massive open online courses: Innovation in education? In R. McGreal, W. Kinuthia, \& S. Marshall (Eds.), Open educational resources: Innovation, research and practice (pp. 5-15). Athabasca, Canada: Athabasca University Press. Retrieved from https://oerknowledgecloud.org/sites/oerknowledgecloud.org/files/pub_PS_OERIRP web.pdf\#page $=31$

Ulrich, C., \& Nedelcu, A. (2015). MOOCs in our university: Hopes and worries. Procedia - Social and Behavioral Sciences, 180, 1541-1547. https://doi.org/10.1016/j.sbspro.2015.02.304

UNESCO. (2013). Alfabetización y Educación. Lecciones desde la Práctica Innovadora de América Latina y el Caribe [Literacy and education: Lessons from innovative practice in Latin America and the Caribbean]. Santiago de Chile, Chile: OREALC/UNESCO. Retrieved from https://unesdoc.unesco.org/ark:/48223/pf0000219157 
Vaibhav, A., \& Gupta, P. (2015). Gamification of MOOCs for increasing user engagement. In Proceedings of the 2014 IEEE International Conference on MOOCs, Innovation and Technology in Education (pp. 290-295). IEEE. http://doi.org/10.1109/MITE.2014.7020290

Valdivia Vazquez, J., Villegas, A., Farías, S. \& Aldape, L. (2017) Evaluación de las experiencias en el desarrollo e implementación de MOOC de energía [Evaluation of experiences in the development and implementation of energy MOOCs]. In M. S. Ramírez-Montoya \& A. Mendoza-Domínguez (Eds.), Innovación y sustentabilidad energética: Formación con MOOCs e investigación educativa (pp. 1534). Madrid, Spain: Narcea.

Vázquez-Cano, E., López-Meneses, E., \& Sarasola, J. L. (2013). La expansión del conocimiento en abierto: Los MOOCs [The expansion of open knowledge: MOOCs]. Barcelona, Spain: Octaedro.

Villalustre-Martínez, L., \& Del Moral-Pérez, M. E. (2015). Gamification: Strategies to optimize learning process and the acquisition of skills in university contexts. Digital Education Review, 27, 13-31. Retrieved from http://revistes.ub.edu/index.php/der/article/view/12486/pdf_1

Werbach, K., \& Hunter, D. (2012). For the win: How game thinking can revolutionize your business. Philadelphia, PA: Wharton Digital Press.

Werbach, K., \& Hunter, D. (2015). The gamification toolkit. Philadelphia, PA: Wharton Digital Press.

Willems, C., Fricke, N., Meier, S., Meissner, R., Rollmann, K., Voelcker, S., \& Meinel, C. (2014). Motivating the masses: Gamified massive open online courses on Openhpi. In EDULEARN14: Proceedings of the 6th International Conference on Education and New Learning Technologies (pp. 4042-4052). Valencia, Spain: IATED. Retrieved from https://library.iated.org/view/WILLEMS2014MOT

Williams, I. (2015, October). Gamification as a content marketing tactic. Smart Insights. Retrieved from http://www.smartinsights.com/content-management/content-marketing-creative-andformats/gamification-as-a-content-marketing-tactic/

Xing, W., Chen, X., Stein, J., \& Marcinkowski, M. (2016). Temporal predication of dropouts in MOOCs: Reaching the low hanging fruit through stacking generalization. Computers in Human Behavior, 58, 119-129. https://doi.org/10.1016/j.chb.2015.12.007

Zhou, M. (2016). Chinese university students' acceptance of MOOCs: A self-determination perspective. Computers \& Education, 92-93, 194-203. http://doi.org/10.1016/j.compedu.2015.10.012

Corresponding author: Elvira G. Rincón-Flores, elvira.rincon@tec.mx

Copyright: Articles published in the Australasian Journal of Educational Technology (AJET) are available under Creative Commons Attribution Non-Commercial No Derivatives Licence (CC BY-NC-ND 4.0). Authors retain copyright in their work and grant AJET right of first publication under CC BY-NC-ND 4.0.

Please cite as: Rincón-Flores, E. G., Mena Marcos, J. J., Ramírez-Montoya, M. S., Ramírez Velarde, R. (2020). The use of gamification in xMOOCs about energy: Effects and predictive models for participants' learning. Australasian Journal of Educational Technology, 36(2), 43-59. https://doi.org/10.14742/ajet.4818 